\title{
ESTIMATING BIGHORN SHEEP (OVIS CANADENSIS) ABUNDANCE USING NONINVASIVE SAMPLING AT A MINERAL LICK WITHIN A NATIONAL PARK WILDERNESS AREA
}

\author{
Kathryn A. Schoenecker ${ }^{1}$, Mary Kay Watry ${ }^{2}$, Laura E. Ellison ${ }^{3}$, \\ Michael K. Schwartz ${ }^{4}$, and Gordon Luikart 5
}

\begin{abstract}
Conservation of species requires accurate population estimates. We used genetic markers from feces to determine bighorn sheep abundance for a herd that was hypothesized to be declining and in need of population status monitoring. We sampled from a small but accessible portion of the population's range where animals naturally congregate at a natural mineral lick to test whether we could accurately estimate population size by sampling from an area where animals concentrate. We used mark-recapture analysis to derive population estimates, and compared estimates from this smaller spatial sampling to estimates from sampling of the entire bighorn sheep range. We found that estimates were somewhat comparable; in 2009, the mineral lick sample and entire range sample differed by 20 individuals, and in 2010 they differed by only one individual. However, we captured 13 individuals in the entire range sample that were not captured at the mineral lick, and thus violated a model assumption that all individuals had an equal opportunity of being captured. This eliminated the possibility of inferring a total population estimate from just animals visiting the mineral lick, but because estimates were relatively similar, monitoring at the mineral lick can provide a useful index for management and conservation. We compared our results to a radio-collar study conducted in 2003-2004 and confirmed that the population remained stable since 2004. Our population estimates were 78 (CI 62-114) in 2009 and 95 (CI 77-131) in 2010. Between 7 and 11 sampling dates were needed to achieve a CV of $20 \%$ for population estimates, assuming a capture probability between 0.09 and 0.13 . We relied on citizen science volunteers to maximize data collection and reduce costs; $71 \%$ of all fecal samples were collected by volunteers, compared to $29 \%$ collected by paid staff. We conclude that our technique provides a useful monitoring tool for managers. The technique could be tested and applied in similar populations where animals congregate with high fidelity at a mineral lick or other area.
\end{abstract}

RESUMEN.-La conservación de las especies requiere estimaciones precisas de la población. Utilizamos marcadores genéticos de las heces para determinar la abundancia de una manada de borrego cimarrón que hipotéticamente estaba disminuyendo y por la necesidad del monitorear el estado de la población. Tomamos muestras de una pequeña pero accesible parte de la población en la que los animales se congregan de forma natural en una capa mineral natural para intentar estimar con precisión el tamaño de la población mediante el muestreo de un área donde los animales se concentran. Utilizamos análisis de marca y recaptura para derivar estimaciones de la población, y comparar este muestreo pequeño con el rango espacial completo del borrego cimarrón. Encontramos que las estimaciones son comparables; en el 2009, la muestra del sitio de minerales y la de toda la muestra difirió por 20 individuos, y en 2010 se diferenció sólo por 1 individuo. Sin embargo, capturamos 13 individuos en la muestra completa que no fueron capturados en la muestra del depósito mineral, y por lo tanto se violó el supuesto del modelo de que todos los individuos tenían la misma probabilidad de ser capturado. Esto eliminó la posibilidad de inferir una estimación de la población total de sólo muestrear a los animales que visitan el depósito mineral, pero por ser las estimaciones relativamente similares, monitorear el depósito mineral puede proporcionar un índice útil para la gestión y la conservación. Comparamos nuestros resultados con un estudio de radio collares realizado en 2003-2004 y confirmamos que la población se mantuvo estable desde el 2004. Nuestras estimaciones de la población fue de 78 (IC 62-114) en el 2009 y 95 (IC 77-131) en el 2010. Se necesitan entre 7 y 11 ocasiones de muestreo para alcanzar un CV del $20 \%$ para las estimaciones oblacionales, asumiendo una probabilidad de captura de entre 0.09 y 0.13 . Nos basamos en ciudadanos voluntarios para maximizar la colección de datos y reducir los costos; $71 \%$ de todas las muestras fecales fueron colectadas por los voluntarios, en comparación con el $29 \%$ colectado por el personal remunerado. Concluimos que nuestra técnica proporciona una herramienta útil para los responsables de la conservación para el seguimiento, y podría ser probado y aplicado en poblaciones similares donde los animales se congregan con alta fidelidad en una capa mineral u otra área.

Any use of trade, product, or firm names is for descriptive purposes only and does not imply endorsement by the U.S. Government.

${ }^{1}$ U.S. Geological Survey, Fort Collins Science Center, and Department of Ecosystem Science and Sustainability, Colorado State University, Fort Collins, CO 80523. E-mail: schoeneckerk@usgs.gov

${ }^{2}$ Resources Management, Rocky Mountain National Park, 1000 Highway 36, Estes Park, CO 80517.

${ }^{3}$ U.S. Geological Survey, Fort Collins Science Center, Fort Collins, CO 80526

${ }^{4}$ U.S. Forest Service, Rocky Mountain Research Station, Missoula, MT 59801.

${ }^{5}$ Flathead Lake Biological Station, Division of Biological Sciences, University of Montana, Polson, MT 59860. 
Novel approaches to monitor abundance are needed for the conservation of populations inhabiting remote and vast locations such as wilderness areas. The Wilderness Act of 1964 (16 U.S. C. 1131-1136) established a system of federal lands set aside as Wilderness areas that are mandated to be left unimpaired for future use and where "wilderness character" is preserved. The act defines wilderness ". . . in contrast with those areas where man and his own works dominate the landscape, [wilderness] is hereby recognized as an area where the earth and its community of life are untrammeled by man, where man himself is a visitor who does not remain." There are very few published studies on the benefits of wilderness to wildlife (Kershner et al. 1997, Rominger et al. 2004, Vucetich et al. 2012). This may be due to limitations on access and equipment; in some wilderness areas, stream temperature loggers and PIT (Passive Integrative Transponder) tag readers are considered installations and contrary to the goal of maintaining wilderness character. Satellite- and radio-collars have been viewed by some wilderness managers as impacting the natural, untrammeled, and undeveloped elements of wilderness character.

Noninvasive genetic sampling is a powerful conservation tool for estimating population size and other population attributes (Schwartz et al. 2007, Luikart et al. 2008a, 2008b, 2010), yet we lack understanding of the usefulness of this sampling approach for inaccessible wild landscapes. A major challenge of using noninvasive sampling for monitoring is the substantial time and effort required to repeatedly collect enough samples from populations distributed across large landscapes, including remote wilderness areas. This challenge could be partially resolved if sampling could be limited to a subsection of the range where animals naturally congregate, such as a feeding or watering area, or mineral lick.

Use of DNA from noninvasively collected samples to identify individuals and estimate population abundance has been successful for various carnivores and omnivores (Taberlet et al. 1997, Ernest et al. 2002, Wilson et al. 2003, Prugh et al. 2005, Solberg et al. 2006, Kendall et al. 2008, Ruell et al. 2009, Stenglein et al. 2010). DNA identification has been used less frequently for ungulates (Valière et al. 2007, Van Vliet et al. 2008, Brinkman et al. 2011, Hettinga et al. 2012) possibly limited by low success rates or high genotyping errors with corresponding large bias in population estimates (Waits and Leberg 2000, Waits and Paetkau 2005). Herbivores are also challenging because plant secondary compounds in their diets can inhibit polymerase chain reactions (PCR; Wehausen et al. 2004). Recent advances have improved analysis techniques and strengthened the usefulness of DNA-based approaches by addressing some of the expected problems with ungulates, such as allelic dropout (McKelvey and Schwartz 2004, Wehausen et al. 2004, Luikart et al. 2008a, 2010).

DNA-based sampling is applicable in landscapes where traditional aerial surveys for population monitoring are logistically challenging, where ground searches are not reliable or random (Brinkman et al. 2011), and where wilderness character is a concern (Schwartz et al. 2011). In addition, marking and handling animals has become less acceptable to the public and particularly less desirable in national parks (Fix et al. 2010). Handling causes stress to the animal and risk to handlers, and can result in capture myopathy leading to animal mortality even with optimal capture methods (Kock et al. 1987).

Recent research in Rocky Mountain National Park, Colorado, determined that the population of Rocky Mountain bighorn sheep (Ovis canadensis canadensis) on the east side of the park was approaching its lowest numbers in the park's recorded history (McClintock and White 2007). McClintock and White (2006) reported that if parameter estimates for the herd from 2004-2005 were used in a deterministic Leslie matrix model, the population would be projected to go extinct by 2016 . The population resides primarily within habitat that was designated as wilderness in 2006 (HR 6245 US House of Congress). Bighorn sheep are one of the park's highest priorities for management, and are a primary attraction for wildlife viewing because of their high visibility to park visitors. A volunteer group called The Bighorn Brigade was established by the park to facilitate bighorn sheep viewing and partially mitigate disturbance to bighorn sheep from visitors. The Bighorn Brigade manages hundreds of visitors each summer who come to observe bighorn sheep at a natural mineral lick in the park, often halting traffic so bighorn sheep can cross the road (Fig. 1). This is the only known mineral lick in the east side bighorn sheep range. 


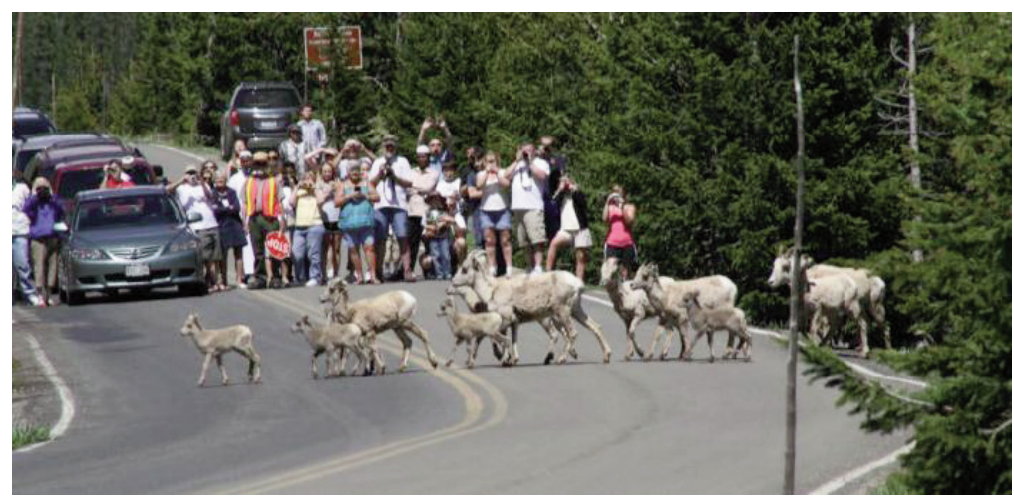

Fig. 1. Traffic is halted to allow a group of bighorn lambs and ewes to cross a main park road. Bighorn sheep congregate at a natural mineral lick intermittently from May to September each year in Rocky Mountain National Park, Colorado. The road separates the mineral lick from the rest of their range. Photo credit: Rocky Mountain National Park.

Mineral lick use by wild sheep strongly influences their distribution and movements (Palmer 1941, Viereck 1963, Pitzman 1970, Erickson 1970). Use of a mineral lick to count wild sheep has been successful (Heimer 1973) where multiple returns of marked sheep to the lick allowed estimation of the population size. In one study, the probability of ewes returning to the lick in that study was $100 \%$ (Nicholas and Heimer 1972). We evaluated the usefulness of a noninvasive genetic approach to monitor the bighorn sheep population in Rocky Mountain National Park by sampling from a relatively small but accessible portion of the herd's range, where the animals congregate at a mineral lick. Collecting and genotyping shed DNA, usually in the form of feces or hair, can be considered equivalent to identifying the individual that deposited the genetic sample. Mark-recapture models can then be used to estimate population size (Seber 1986, Pollock et al. 1990, Lebreton et al. 1992, Prugh et al. 2005). We used fecal pellets from bighorn sheep and closed capture models to estimate population size, and we developed our fecal collection sampling design to evaluate the need for backcountry surveys in park wilderness. A key question in our study was whether the same bighorn sheep observed in backcountry wilderness areas also visited the natural mineral lick in the "front country" during summer. In a previous bighorn sheep study in Rocky Mountain National Park there was a backcountry fatality during ground surveys and a helicopter accident during bighorn sheep radio-collaring. These tragedies underscore the risks of backcountry wildlife work and aerial capture programs, and the importance of developing safer survey and noninvasive methods when possible (Heimer 1994). Thus, our objectives included genotyping individual bighorn sheep located in backcountry wilderness to see if the same individuals also occurred at the mineral lick. If so, we could potentially develop monitoring protocols that reduce the need for backcountry travel. We tested the hypothesis that sampling mainly from a lower-elevation front-country area of the population's range could give accurate and precise estimates of population abundance. Lastly, we compared our population estimates to a radio mark-recapture study (McClintock and White 2007) to :/determine whether the east side bighorn sheep population had remained stable or continued to decline.

\section{Methods \\ Study Area}

The bighorn sheep population inhabits the east side of Rocky Mountain National Park, Colorado, in the southern two-thirds of the Mummy Range and eastward along Fall River and Cow Creek-an area of approximately $170 \mathrm{~km}^{2}$ (McClintock and White 2007; Fig. 2). Approximately $98 \%$ of the east side bighorn population range is within designated wilderness. Elevations range from 2340 to $4130 \mathrm{~m}$. Precipitation averages $41 \mathrm{~cm}$ at lower elevations to $66 \mathrm{~cm}$ in higher regions, mostly occurring as heavy, wet snow in March and April (Stevens 1982). Vegetation is primarily 

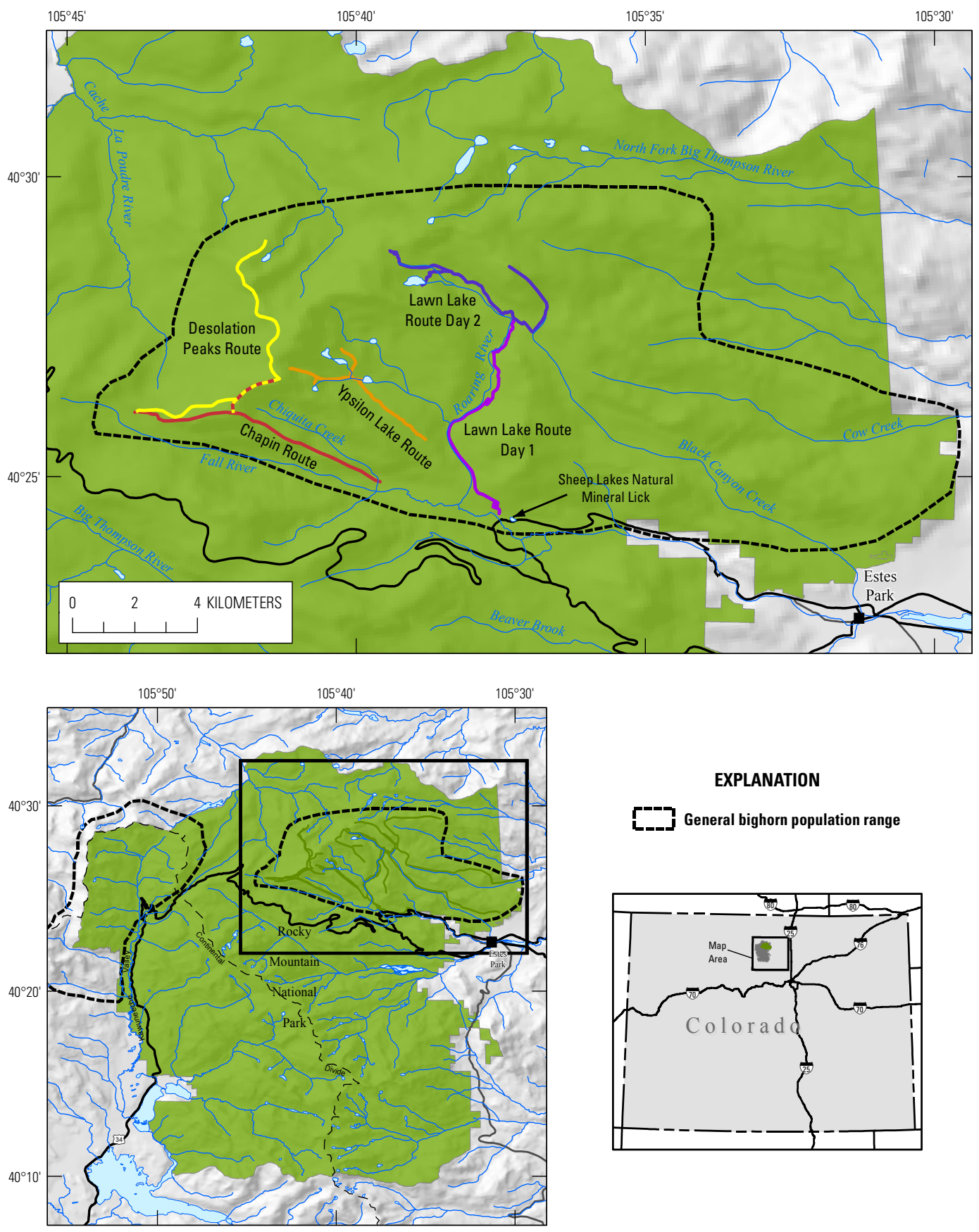

EXPLANATION

\section{General bighorn population range}

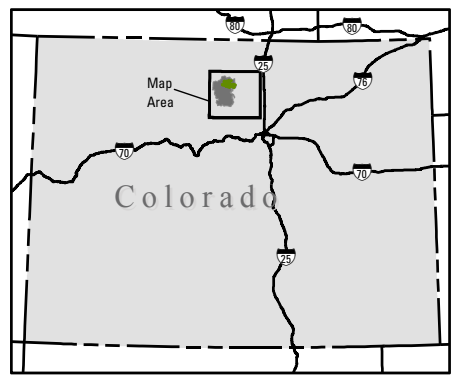

Fig. 2. Bighorn sheep range for the east side population in Rocky Mountain National Park, Colorado. Colored lines are backcountry survey routes, and the natural mineral lick at Sheep Lakes is indicated. Insets show location of the east side population within Rocky Mountain National Park (RMNP) and the location of RMNP within Colorado.

alpine-tundra (50\%), with $37 \%$ subalpine forest and 13\% upper montane forest (Baumann 1978). Lower elevations are characterized by mountain shrub communities with stands of ponderosa pine (Pinus ponderosa), Douglasfir (Pseudotsuga menziesii), aspen (Populus 
tremuloides), and lodgepole pine (Pinus contorta) (Goodson 1980, Stevens 1982). Terrain is rugged with steep cliffs, rock faces, and talus in higher mountains and canyons along the foothills (Goodson 1980). We focused on 2 distinct areas of bighorn sheep habitat: the natural mineral lick at Sheep Lakes in the "front country" and backcountry areas surveyed in McClintock (2004) (Fig. 2). A paved road runs along Sheep Lakes, and a parking lot was established for visitors that come to view bighorns congregating at the natural mineral lick in summer. The area is easily accessible to resource managers and the public. Backcountry sites were roadless, within wilderness designation, and within the area determined to be part of the east side bighorn sheep population and known bighorn sheep habitat (McClintock and White 2007; Fig. 2).

\section{Field Collection of Samples}

We collected bighorn sheep fecal samples between May and October in 2009 and 2010 at the Sheep Lakes mineral lick and backcountry wilderness locations. We visually observed bighorn sheep and collected freshly deposited fecal pellets with disposable forceps, toothpicks, or latex gloves after the sheep moved away from the immediate area. We placed 3-4 fecal pellets into a $20-\mathrm{mL}$ sample tube filled with a $95 \%$ dehydrant (ethyl alcohol, EtOH). We collected a replicate sample from each pile for a total of $6-8$ pellets separated in two 20 -mL tubes. We did not collect fecal pellets if (1) there was uncertainty about whether all pellets belonged to the same animal, (2) the pellets did not appear fresh, (3) the pellets were in water, or (4) there was a recent large rain event which could either wash off mucus containing the epithelial cell DNA from the outside of pellets (Poole et al. 2011), increase DNA degradation rates (Brinkman et al. 2010), or make samples "appear" fresh. We stored samples in a field cooler with ice until we were able to refrigerate them. We shipped samples via overnightdelivery to the lab within 2 weeks of field collection. For each sample, we recorded date, observer/collector, location of sample determined with a global positioning system (GPS), time of defecation (if known), time collected, number of pellets collected, and sex/age classification when possible following Hansen and Deming (1980).
We conducted backcountry wilderness field sampling using ground survey routes that were developed for a radio-collar mark-resight study of this bighorn sheep population (McClintock and White 2006) and used these routes for the collection of fecal pellets. Observers followed ground survey routes and searched for bighorn sheep using binoculars and spotting scopes. Once bighorn sheep were located, they were monitored and feces collected usually within 60 min of sighting. Resighting routes were in Chiquita Creek drainage, Ypsilon Creek drainage, and Roaring River drainage (Fig. 2). We added a route on Desolation Peaks in 2010. Each resighting route was surveyed 2-3 times during the period of mid-July to mid-August and 2-3 times again between mid-August and mid-September during this relatively snow-free 2 -month window.

For front country sampling at the mineral lick, we collected fecal samples from early May through mid-August. Trained volunteers and members of the Bighorn Brigade were stationed at Sheep Lakes. If a fecal collections volunteer was not available, NPS staff would visit the site at the end of the day, inquire of the Bighorn Brigade whether bighorns had visited the mineral lick that day. If so, the NPS staff would record their location and collect samples. We collected a total of 134 samples in 2009 and 168 samples in 2010.

\section{DNA Extractions and Genotyping}

We conducted DNA analyses at the U.S. Forest Service Wildlife Genetics Laboratory in Missoula, Montana. We extracted DNA from pellet samples and analyzed each sample using a panel of 8 microsatellite loci (AE16, HH62, MAF209, MAF33, ADC, TCRG4, MMP9, and FCB266) plus one sex identification locus (amelogenin). To minimize genotyping error we repeat-genotyped each sample 3-4 times independently per locus (Taberlet and Luikart 1999, Maudet et al. 2004) and then used program DROPOUT to screen for errors (McKelvey and Schwartz 2004). Any sample which failed at $>30 \%$ of the loci was dropped from analysis; samples that showed signs of allelic dropout were reamplified.

\section{Mark-Recapture Analysis}

We used closed capture models in Program MARK to estimate population size of bighorn sheep on the east side of the park (Otis et al. 
1978, Bellemain et al. 2005, Solberg et al. 2006, Lukacs 2013). We conducted analyses for the east side population in 2 groupings to determine how important backcountry samples were to total population estimates and whether population size estimates were comparable between bighorn sheep encountered at Sheep Lakes alone and bighorn sheep encountered over their entire range (Sheep Lakes plus backcountry areas). Thus we created 4 separate capture histories: 2009 Sheep Lakes, 2009 Sheep Lakes plus backcountry, 2010 Sheep Lakes, and 2010 Sheep Lakes plus backcountry. We assumed the east side population was closed to emigration and immigration during a summer. This assumption was corroborated by McClintock and White (2007), who found that the east side population was a separate population from other subpopulations in the park, and by fecal data collected from adjacent bighorn sheep subpopulations, in which no bighorn sheep from Sheep Lakes were found to have moved to adjacent herds within the same summer (unpublished data).

One criticism of DNA-based capturerecapture studies is that the concept of a sampling occasion is poorly defined (Lukacs 2005). To define our capture occasions, we created separate capture histories for individuals on a weekly basis from May through August in 2009 and 2010. We then collapsed the total number of individual histories into 4 capture occasions based on month of sampling. In both 2009 and 2010, the first occasion included captures from May, the second from June, the third from July, and the fourth from August. Backcountry samples were only collected in July and August due to inaccessibility prior to those months, and were included in pooled estimates for those occasions only. We ran 4 models for each capture history in Program MARK: constant capture probability $(p)\left(\mathrm{M}_{0}\right.$ in Otis et al. 1978 notation), time varying $p\left(\mathbf{M}_{t}\right)$, behavioral response $\left(\mathbf{M}_{b}\right)$, and heterogeneous $p\left(\mathbf{M}_{h}\right)$. We used the sample size-adjusted Akaike's information criterion $\left(\mathrm{AIC}_{c}\right)$ and $\mathrm{AIC}_{c}$ weights to evaluate the relative support for each candidate model. We ran simulations in Program MARK to investigate the relationship between number of occasions, population size, and capture probabilities to determine optimal sampling occasions for collecting fecal DNA (20\% coefficient of variation $[\mathrm{CV}]$ around the mean population size).

\section{Results}

\section{DNA Extractions}

We identified 61 individuals in 2009 and 53 individuals in 2010 from fecal DNA analyses. In 2009, 3 males were captured in the backcountry at Chapin and Old Fall River that were not captured in the front country mineral lick at Sheep Lakes. In 2010, there were 10 individuals identified in the backcountry at Lawn Lake but not captured at the mineral lick (8 females, 2 unknowns).

We obtained quality DNA for genotyping from 113 of 134 fecal samples $(84.3 \%)$ in 2009 , and 133 of $168(83.9 \%)$ in 2010 . We reextracted DNA from 8 of the 35 lower-quality samples from 2010. All 8 were from Sheep Lakes and yielded high-quality genotypes on the second extraction using a different pellet from the same sample tube. The remaining 27 lowerquality samples were never extracted or quality tested because they did not have "pellet form" feces or had discolored DNA extractions, which can reduce genotyping success (Maudet et al. 2004). Most samples that we did not extract were collected in early May/June when DNA quality was poor, probably because this earlier period was wetter compared to July-September. Only 58\% of samples collected before 17 June had high-quality genotypes compared to $85 \%$ after 16 June.

Power of the 9 loci used to identify individuals was high relative to the small population with relatively small sets of siblings (e.g., 1 lamb per female per year). The cumulative probability of identity (PI) is defined as the probability of randomly sampling 2 individuals that actually, by chance, have identical genotypes at the loci studied (Taberlet et al. 1997, Waits and Leberg 2000). The PI in our study was 7.5 in $100,000,000$ for the population at large or 1.04 in 1000 for random pairs of siblings (Table 1). Among the 9 loci, no individuals differed by only one allele; one pair of individuals differed by only 2 alleles. All remaining individuals differed by $>2$ alleles, as would be expected for data sets with highly polymorphic loci and genotyping errors removed. The probability of seeing multilocus genotypes with only 1 or 2 allele mismatches was low and might signal that unique genotypes are being generated by genotyping errors. This has been observed in other studies and is termed "the shadow effect” (Mills et al. 2000). Our data showed 
TABLE 1. Cumulative probability of identity (PI) for 2 randomly sampled individuals or siblings for east side bighorn sheep sampled in 2009 and 2010 in Rocky Mountain National Park, Colorado. The PI is defined as the probability of randomly sampling 2 individuals that actually, by chance, have identical genotypes at the loci studied (Waits and Leberg 2000). Note that as more loci are included (moving down the table) the cumulative probability of identity decreases.

\begin{tabular}{llc}
\hline Locus & PI: Individuals & PI: Siblings \\
\hline AMELO & 0.4549 & 0.6764 \\
TCRG4 & 0.1271 & 0.3776 \\
MMP9 & $1.001 \times 10^{-2}$ & 0.1426 \\
MAF209 & $1.439 \times 10^{-3}$ & $6.204 \times 10^{-2}$ \\
FCB266 & $2.321 \times 10^{-4}$ & $2.845 \times 10^{-2}$ \\
HH62 & $4.114 \times 10^{-5}$ & $1.386 \times 10^{-2}$ \\
ADC & $4.942 \times 10^{-6}$ & $5.765 \times 10^{-3}$ \\
MAF33 & $8.390 \times 10^{-7}$ & $2.678 \times 10^{-3}$ \\
AE16 & $7.519 \times 10^{-8}$ & $1.042 \times 10^{-3}$ \\
\hline
\end{tabular}

TABLE 2. Sampling location, year, total number of sample dates, number of individuals, population size $(N)$ estimates, and capture probability $(p)$ estimates for the east side population of bighorn sheep at Rocky Mountain National Park, Colorado, 2009 and 2010. The total number of sample dates was collapsed into 4 capture occasions for Program MARK analyses. The closed population model with constant probability of capture was used to estimate $N$ and $p\left(\mathrm{M}_{0}\right.$ of Otis et al. 1978).

\begin{tabular}{|c|c|c|c|c|c|c|c|c|c|}
\hline $\begin{array}{l}\text { Sampling } \\
\text { location }\end{array}$ & Year & $\begin{array}{c}\text { Number of } \\
\text { sample } \\
\text { dates }\end{array}$ & $\begin{array}{l}\text { Number of } \\
\text { genotyped } \\
\text { individuals }\end{array}$ & $N$ & SE & $95 \% \mathrm{CI}$ & $p$ & $\mathrm{SE}$ & $95 \%$ CI \\
\hline Sheep Lakes & 2009 & 15 & 34 & 58 & 11.3 & $44-91$ & 0.13 & 0.03 & $0.08-0.21$ \\
\hline $\begin{array}{l}\text { Sheep Lakes } \\
\quad+\text { Backcountry }\end{array}$ & 2009 & 18 & 46 & 78 & 12.8 & $62-114$ & 0.10 & 0.02 & $0.07-0.15$ \\
\hline Sheep Lakes & 2010 & 19 & 44 & 94 & 20.9 & $67-153$ & 0.09 & 0.03 & $0.06-0.16$ \\
\hline $\begin{array}{l}\text { Sheep Lakes } \\
\quad+\text { Backcountry }\end{array}$ & 2010 & 23 & 57 & 95 & 13.6 & $77-131$ & 0.12 & 0.02 & $0.08-0.17$ \\
\hline
\end{tabular}

no evidence that genotyping error generated false multilocus genotypes leading to "new individuals."

\section{Sex Identification}

In 2010,123 of 133 fecal samples (92\%) were successfully genotyped at the sex ID locus amelogenin (AMELO). Seventy-nine were identified as females, 44 were identified as males, 4 were inconclusive, and 6 did not yield a genotype. Those successfully genotyped had at least 2 independent replicate genotypings that were clearly/easily scored at the amelogenin locus. We used 28 samples classified to gender in the field to compare with lab results, and genetic sex ID matched field classifications $89 \%(25 / 28)$ of the time. For all 3 mismatches, samples were identified as ewes in the field but as males by genotype.

We found seasonal differences between male and female bighorn sheep in the timing of visits to the mineral lick. Males visited Sheep Lakes early in the season (May) and did not return for the remainder of the summer. Female groups visited throughout the summer and early fall.

\section{Mark-Recapture Analysis}

The best model chosen by $\mathrm{AIC}_{c}$ varied by capture history and year for each of the 4 data sets; however, capture probabilities were too low for models with more structure $\left(\mathrm{M}_{b}, \mathrm{M}_{h}\right.$, and $\mathrm{M}_{t}$ ) to either reach convergence or provide accurate estimates of $N$ and $p$. Population sizes were estimated to be higher when we used both Sheep Lakes and backcountry samplesby 20 individuals in 2009 and by 1 individual in 2010 (Table 2). Capture probabilities of individuals varied by year and location, with a high of 0.13 at Sheep Lakes during the 2009 summer sampling. In 2009, the capture probability was 0.03 higher at Sheep Lakes than when backcountry routes were included. Conversely, in 2010 the capture probability for Sheep Lakes plus backcountry was 0.03 higher than for Sheep Lakes only.

We ran simulations in Program MARK using the lowest and highest population estimates and capture probabilities from Table 2. These simulations revealed that for a population size of 58 bighorn sheep and $p=0.09$, the number of sampling occasions needed 
for a $20 \%$ coefficient of variation $(\mathrm{CV})$ was 11 . When $p$ was increased to 0.13 , the number of occasions needed for a $20 \% \mathrm{CV}$ was 7 . For a population of 95 bighorn sheep and $p=0.09$, the number of sampling occasions needed for a $20 \% \mathrm{CV}$ was 9 ; by increasing $p$ to 0.13 , the number of occasions needed was reduced to 6 .

\section{Discussion}

Noninvasive fecal pellet collections provided samples of sufficient quality to identify individual bighorn sheep using DNA and provide statistically robust population estimates. Not all backcountry individuals were captured at the mineral lick at least once during each year's sampling, yet this had a relatively small impact on final population estimates, especially in 2010 when sample sizes were larger. However, backcountry sampling added sufficient precision to warrant inclusion in surveys. Including backcountry samples in 2009 provided a similar variance and a 34\% higher population estimate. In 2010 , the population estimate was similar, but the variance with backcountry samples was much tighter. So although the mineral lick is the main sampling area, backcountry sampling provided considerable value and greater accuracy to population estimates. Managers could consider conducting monitoring at the mineral lick annually, and collecting backcountry samples every $2-5$ years for a full population count.

Our results confirm that the east side bighorn sheep population size remained stable between 2004 and 2010. McClintock and White (2007) estimated 77.5 (CI 52.3-115.0) bighorn sheep in 2003 and 61.4 (CI 56.0-81.7) bighorn sheep in 2004 and our estimates were 78 (CI 62-114) in 2009 and 95 (CI 77-131) in 2010.

Field classification error of sex was low, but what error existed was biased against males; bighorn sheep were field-classified as females but genotyped as males in the lab. Field crews need to evaluate sex of bighorn sheep using both horns and genitals, not just horn size, so that yearling males are not misclassified as ewes.

Appropriately designed mark-recapture studies must ensure that all individuals in a population have a nonzero probability of capture. If pellets of some individuals have no probability of being collected, then population estimates would be biased low. This was the case for the Sheep Lakes-only sample where some individuals were not "captured." Sampling effectively also requires maximizing encounter rates with viable samples. By focusing collections at the mineral lick where animals naturally congregate, plus conducting additional sampling in the backcountry, we maximized encounter rates. Bighorn sheep were sighted on backcountry survey routes for several years in a previous study (McClintock and White 2007), and we added an additional route in 2010. Also, the timing of sampling was important. Our sampling protocol spanned the time period from late spring through late summer. Males used the mineral lick earlier in the season, so sampling in late April or early May enabled a better count of males.

Remotely collected genetic data do not always conform to traditional mark-recapture designs, and within-session recaptures may not provide information about new individuals, particularly when samples are collected closely in time or space. With the exception of backcountry samples, our fecal samples primarily originated from one location (the mineral lick). We addressed this lack of independence in our fecal data by using traditional closed capture modeling (MARK), which explicitly considers heterogeneity in capture probabilities and has been recommended for such data sets (Harris et al. 2010). Mark-recapture models also assume independence in individual capture probabilities. This assumption was violated in our data set because dependent lambs were with ewes in summer, and we could not remove these individuals from our data set because we could not determine age by DNA analysis. However, simulations indicate that inclusion of dependent offspring causes minimal bias to population estimates but potentially a slight negative bias to variance estimates (Miller et al. 1997), suggesting our population estimates are minimally biased, but variance estimates may be slightly low.

Genotyping error causes bias in fecal DNA data sets, which can result in dramatic biases in population estimates (Creel et al. 2003). Underestimating the real number of unique individuals due to the shadow effect (Mills et al. 2000) or falsely identifying unique individuals (Waits and Leberg 2000) reduces confidence in resulting population estimates. By using a minimum of 8-9 loci recommended by 
McKelvey and Schwartz (2004) and 3-4 PCR amplifications over multiple tubes (Bonin et al. 2004), we had relatively low genotyping error (Creel et al. 2003, Pompanon et al. 2005).

Male bighorn sheep tend to be more solitary or remain in bachelor groups in the nonbreeding season (Geist 1971) when we collected samples. Thirty-six percent $(36 \%)$ of 2010 genotyped individuals were male. We do not know whether males moved out of the study area after May (when we no longer regularly observed them at the mineral lick) or whether they were missed on backcountry surveys. Although males travel greater distances than females, we believe we captured a significant segment of the male population because of the broad temporal and spatial range of sampling, because we genotyped so many from samples at the mineral lick in May, and because rams per 100 ewes in our study was greater than data from 2003 and 2004 in McClintock and White (2007), which indicated 46.9 rams per 100 ewes in 2003 and 33.8 rams per 100 ewes in 2004. Our data indicated 55.7 rams per 100 ewes in 2010.

Between 7 and 11 sampling dates were needed to achieve a $\mathrm{CV}$ of $20 \%$ for population estimates, assuming a capture probability of between 0.09 and 0.13. This is an achievable metric for field sampling. Rocky Mountain National Park has a robust citizen science program and engages the public using local volunteers. In our study, $71 \%$ of all fecal samples were collected by volunteers, compared to $29 \%$ collected by paid staff. By focusing fecal sample collections in the front country, park staff can use citizen science volunteers to reduce monitoring costs for bighorn sheep and collect samples over a broad temporal period throughout summer. In addition, costs for laboratory analyses have decreased over time, increasing the viability of noninvasive genetic population monitoring for management of bighorn sheep and providing a useful alternative to radio-collar marking. Radiocollaring is expensive, and it is difficult to maintain radio-collars over time in sufficient numbers required for monitoring. Our sampling protocol, survey design, and citizen science approach have application to other bighorn sheep populations, can contribute to long-term monitoring and management of bighorn sheep, and provide a valuable tool to track population trends for this and other populations, especially in areas where noninvasive monitoring tools are preferred.

\section{ACKNOWLEDGMENTS}

We are grateful to field technicians and volunteers including G. Althen, J. AmesCurtis, G. Anderson, G. Appel, G. Baird, C. Bell, B. Bolinger, B. Cairns, L. Campbell, G. Campbell, L. Carr, L. Carr, M. Clapp, M. Cramer, J. Cramer, K. Cronin, J. DeRuiter, E. Ertl, R. Gallardo, C. Gerhard, M. Grether, D. Hay, M. Huba, F. Jacoby, T. Jones, W. Kaesler, J. Kilgore, L. Kilgore, D. Kuntz, S. Lauffer, J. Lawton, K. Long, D. Long, L. Messersmith, G. Miller, J. Murray, M.L. O’Neil, I. Petkash, J. Pina, J. Porter, C. Prickett, F. Renner, K. Snow, A. Strom, R. Stuart, R. Toll, D. Tuttle, S. Tuttle, J. Vida, J. Webster, S. Yates, R. Yates, and members of the Bighorn Brigade for assistance in field sample collections. We thank T. Stanley for assistance with markrecapture simulations, and J. Visty for overall project support. We thank S. Amish, M. Childs, and K. Pilgrim for assistance with DNA lab analyses. This project was funded by the Park Oriented Biological Support Program, U.S. Geological Survey, Washington, DC. Support for G.L. was provided in part by NSF grants DEB-1067613 and 0742181. Any use of trade names or products does not imply endorsement by the U.S. government.

\section{Literature Cited}

BaUmanN, T.G. 1978. Winter ecology of bighorn sheep in the Mummy Range, Colorado. Master's thesis, Colorado State University, Fort Collins, CO.

Bellemain, E., J.E. Swenson, D. Tallmon, S. BrunBERG, AND P. TABERLET. 2005. Estimating population size of elusive animals using DNA from huntercollected faeces: comparing four methods for brown bears. Conservation Biology 19:150-161.

Bonin, A., E. Bellemain, P.E. Bronken, F. Pompanon, C. Brachmann, and P. Taberlet. 2004. How to track and assess genotyping errors in population genetics studies. Molecular Ecology 13:3261-3273.

Brinkman, T.J., D.K. Person, F.S. Chapin III, W. Smith, AND K.J. HundERTMARK. 2011. Estimating abundance of sitka black-tailed deer using DNA from fecal pellets. Journal of Wildlife Management 75:232-242.

Brinkman, T.J., M.K. Schwartz, D.K. Person, K.L. PilGRIM, AND K.J. HundERTMARK. 2010. Effects of time and rainfall on PCR success using DNA extracted from deer fecal pellets. Conservation Genetics 11: $1547-1552$.

Creel, S., G. Spong, J.L. Sands, J. Rotella, J. Zeigle, L. Joe, K.M. MurPhy, And D. SMith. 2003. Population size estimation in Yellowstone wolves with error- 
prone noninvasive microsatellite genotypes. Molecular Ecology 12:2003-2009.

Erickson, J.A. 1970. Sheep report. Federal Aid in Wildlife Restoration Annual Project Progress Report, vol. II.

Ernest, H.B., E.S. Rubin, And W.M. Boyce. 2002. Fecal DNA analysis and risk assessment of mountain lion predation of bighorn sheep. Journal of Wildlife Management 66:75-85.

Fix, P.J., T.L. Teel, M.J. Manfredo, and S.S. Boston. 2010. Assessing public acceptance of wildlife management trade-offs: a case study of elk and vegetation management in Rocky Mountain National Park, Colorado. Human Dimensions of Wildlife 15:405-417.

Geist, V. 1971. Mountain sheep. Chicago Press, Chicago, IL. Goodson, N.J. 1980. Bighorn sheep in north-central Colorado: past, present and future. Proceedings of the Biennial Symposium of the North American Wild Sheep and Goat Council 2:190-210.

Hansen, C.G., and O.V. Deming. 1980. Growth and development. Pages 152-171 in G. Monson and L. Sumner, editors, The desert bighorn. University of Arizona Press, Tucson, AZ.

Harris, R.B., J. Winnie Jr., S.J. Amish, A. Beja-Pereira, R. Godinho, V. Costa, and G. Luikart. 2010. Argali abundance in the Afghan Pamir using capturerecapture modeling from fecal DNA. Journal of Wildlife Management 74:668-677.

Heimer, W.E. 1973. Dall sheep movements and mineral lick use. Alaska Department of Fish and Game Final Report, Federal Aid in Wildlife Restoration Projects W-17-2, W-17-3, W-17-4, and W-17-5; Job 6.1R.

Heimer, W.E. 1994. Aerial survey and Dall sheep population size: comparative usefulness of external and internal population dynamics for management purposes. Biennial Proceedings Northern Wild Sheep and Goat Council 9:43-50.

Hettinga, P.N., A.N. Arnason, M. Manseau, D. Cross, K. Whaley, AND P.J. Wilson. 2012. Estimating size and trend of the North Interlake woodland caribou population using fecal-DNA and capture-recapture models. Journal of Wildlife Management 76: $1153-1164$.

Kendall, K.C., J.B. Stetz, D.A. Roon, L.P. Waits, J.B. Boulanger, and D. Paetkau. 2008. Grizzly bear density in Glacier National Park, Montana. Journal of Wildlife Management 72:1693-1705.

Kershner, J.L., C.M. Bischoff, and D.L. Horan. 1997. Population, habitat, and genetic characteristics of Colorado River cutthroat trout in wilderness and non-wilderness stream sections in the Uinta Mountains of Utah and Wyoming. North American Journal of Fisheries Management 17:1134-1143.

Kock, M.D., R.K. Clark, C.E. Franti, D.A. Jessup, and J.D. Wehausen. 1987. Effects of capture on biological parameters in free-ranging bighorn sheep (Ovis canadensis): evaluation of normal, stressed and mortality outcomes and documentation of postcapture survival. Journal of Wildlife Diseases 23:652-662.

Lebreton, J.D., K.P. Burnham, J. Cloberet, and D.R. ANDERSON. 1992. Modeling survival and testing biological hypotheses using marked animals: a unified approach with case-studies. Ecological Monographs 62:67-118.

LuKaCs, P. 2005. Statistical aspects of using genetic markers for individual identification in capturerecapture studies. Doctoral dissertation, Colorado State University, Fort Collins, CO. 132 pp.
LuKaCs, P. 2013. Closed population capture-recapture models. Pages 1-38 in E.G. Cooch and G.C. White, editors, Program MARK: a gentle introduction. 11th edition.

Luikart, G., K. Pilgrim, J. Visty, V.O. Ezenwa, and M.K. SCHWARTz. 2008b. Candidate gene microsatellite variation is associated with parasitism in wild bighorn sheep. Biology Letters 4:228-231.

Luikart, G., N. Ryman, D.A. Tallmon, M.K. Schwartz, AND F.W. Allendorf. 2010. Estimation of census and effective population sizes: the increasing usefulness of DNA-based approaches. Conservation Genetics 11:355-373.

Luikart, G., S. Zundel, D. Riouix, C. Miquel, K.A. Keating, J.T. Hogg, B. Steele, K. Foresman, and P. TABERLET. 2008a. Low genotyping error rates and noninvasive sampling in bighorn sheep. Journal of Wildlife Management 72:299-304.

Maudet, C., G. Luikart, D. Dubray, A. Von HardenBERG, AND P. TABERLET. 2004. Low genotyping error rates in wild ungulate feces sampled in winter. Molecular Ecology Notes 4:772-775.

McClintock, B.T. 2004. The mark-resight method: an application to bighorn sheep in Colorado and a simulation study evaluating estimators. Master's thesis, Colorado State University. Fort Collins, CO. 142 pp.

McClintock, B.T., And G.C. White. 2006. Distribution and abundance of bighorn sheep in Rocky Mountain National Park, Colorado. On file, library of Rocky Mountain National Park, Colorado, USA.

McClintock, B.T., and G.C. White. 2007. Bighorn sheep abundance following a suspected pneumonia epidemic in Rocky Mountain National Park. Journal of Wildlife Management 71:183-189.

McKelvey, K.S., and M.K. Schwartz. 2004. Genetic errors associated with population estimation using non-invasive molecular tagging: problems and new solutions. Journal of Wildlife Management 68:439-448.

Miller, S.D., G.C. White, R.A. Sellers, H.V. Reynolds, J.W. Schoen, K. Titus, V.G. Barnes Jr., R.B. Smith, R.R. Nelson, W.B. Ballard, and C.C. Schwartz. 1997. Brown and black bear density estimation in Alaska using radio telemetry and replicated markresight techniques. Wildlife Monographs 133.

Mills, L.S., J.J. CitTa, K.P. Lair, M.K. SchwartZ, and D.A. Tallmon. 2000. Estimating animal abundance using noninvasive DNA sampling: promise and pitfalls. Ecological Applications 10:283-294.

Nicholas, L., AND W. Heimer. 1972. Sheep report. Federal Aid in Wildlife Restoration Annual Project Progress Report, Volume 8.

Otis, D.L., K.P. Burnham, G.C. White, and D.R. ANDERSON. 1978. Statistical inference from capture data on closed animal populations. Wildlife Monographs 62.

Palmer, L.J. 1941. Dall sheep in the Mount Hayes region. U.S. Fish and Wildlife Service Progress Report. 27 pp.

Pitzman, M.S. 1970. Birth behavior and lamb survival in mountain sheep in Alaska. Master's thesis, University of Alaska College. 116 pp.

Pollock, K.H., J.D. Nichols, C. Brownie, And J.E. HinEs. 1990. Statistical inference for capture-recapture experiments. Wildlife Monographs 107:1-97.

Pompanon, F., A. Bonin, E. Bellemain, and P. Taberlet. 2005. Genotyping errors: causes, consequences and solutions. Nature Review Genetics 6:847-859. dx.doi.org/10.1038/nrg1707 
Poole, K.G., D.M. Reynolds, G. Mowat, and D. Paetkau. 2011. Estimating mountain goat abundance using DNA from fecal pellets. Journal of Wildlife Management 75:1527-1534.

Prugh, L.R., C.E. Ritland, S.M. Arthur, and C.J. KREBS. 2005. Monitoring coyote population dynamics by genotyping faeces. Molecular Ecology 14:1585-1596.

Rominger, E.M., H.A. Whitlaw, D.L. Weybright, W.C. DunN, AND W.B. BaLlard. 2004. The influence of mountain lion predation on bighorn sheep translocations. Journal of Wildlife Management 68:993-999.

Ruell, E.W., S.P.D. Riley, M.R. Douglas, J.P. PolLINGER, AND K.R. CROOKs. 2009. Estimating bobcat population sizes and densities in a fragmented urban landscape using noninvasive capture-recapture sampling. Journal of Mammalogy 90:129-135.

Schwartz, M.K., P.B. LandRES, AND D.J. Parsons. 2011. Wildlife scientists and wilderness managers finding common ground with noninvasive and nonintrusive sampling of wildlife. International Journal of Wilderness 17:4-8.

Schwartz, M.K., G. Luikart, and R.S. Waples. 2007. Genetic monitoring as a promising tool for conservation and management. Trends in Ecology and Evolution 22:25-33.

Seber, G.F. 1986. A review of estimating animal abundance. Biometrics 42:267-292.

Solberg, K.H., E. Bellemain, L. Drageset, P. Taberlet, AND J.E. SwEnson. 2006. An evaluation of field and non-invasive genetic methods to estimate brown bear (Ursus arctos) population size. Biological Conservation 128:158-168.

Stenglein, J.L., L.P. Waits, D.E. Ausband, P. Zager, and C.M. MACK. 2010. Efficient, noninvasive, genetic sampling for monitoring reintroduced wolves. Journal of Wildlife Management 74:1050-1058.

Stevens, D.R. 1982. Bighorn sheep management in Rocky Mountain National Park. Pages 244-253 in Proceedings of the Northern Wild Sheep and Goat Conference, Fort Collins, Colorado, March 17-19, 1982

Taberlet, P., J.J. Camarra, S. Griffin, E. Uhres, O. Hanotte, S.L.P. Waits, C. Dubois-Paganon, T. Burke, And J. Bouvet. 1997. Noninvasive genetic tracking of the endangered Pyrenean brown bear population. Molecular Ecology 6:869-876.

Taberlet, P., and G. LuikarT. 1999. Non-invasive genetic sampling and individual identification. Biological Journal of the Linnaeus Society 68:41-55.

Valière, N., C. Bonenfant, C. ToÏgo, G. Luikart, J.M. GAILLARD, AND F. KLEIN. 2007. Importance of a pilot study for non-invasive genetic sampling: genotyping errors and population size estimation in red deer. Conservation Genetics 8:69-78.

Van Vliet, N., S. Zundel, C. Miguel, P. Taberlet, and R. NASI. 2008. Distinguishing dung from blue, red, and yellow-backed duikers through noninvasive genetic techniques. African Journal of Ecology 46: 411-417. dx.doi.org/10.1111/j.1365-2028.2007.00879.x

ViereCK, L.A. 1963. Survey of range ecology. Pages 6-28 in F.F. Jones and H.R. Merriam, editors, Sheep and goat report. Federal Aid in Wildlife Restoration Annual Project Segment Report; W-6-R-4, Work Plan E, Volume 4.

Vucetich, J.A., M.P. Nelson, and R.O. Peterson. 2012. Should Isle Royale wolves be reintroduced? A case study on wilderness management in a changing world. George Wright Forum 29:126-147.

Waits, J.L., AND P.L. LeberG. 2000. Biases associated with population estimation using molecular tagging. Animal Conservation 3:191-199.

Waits, L.P., and D. PaetKaU. 2005. Noninvasive genetic sampling tools for wildlife biologists: a review of applications and recommendations for accurate data collection. Journal of Wildlife Management 69: 1419-1433.

Wehausen, J.D., R.R. Ramey II, and C.W. Epps. 2004. Experiments in DNA extraction and PCR amplification from bighorn sheep feces: the importance of DNA extraction method. Journal of Heredity 95: 503-509.

Wilson, G.J., A.C. Frantz, L.C. Pope, T.J. Roper, T.A. Burke, C.L. Cheeseman, and R.J. Delahay. 2003. Estimation of badger abundance using faecal DNA typing. Journal of Applied Ecology 40:658-666.

Received 5 September 2014 Accepted 23 March 2015 